\title{
The Effects of Maternal Deprivation on the Hippocampal Structure in Adult Rats
}

\author{
Pınar Karakaş, Memduha Gülhal Bozkır, Fahri Dere, Enver Melik, \\ Emine Babar Melik, Mehmet Kaya, Sait Polat
}

\begin{abstract}
Objectives: To examine the ultrastructural effects of maternal deprivation during developmental periods of limbichypothalamo-pituitary-adrenal system on hippocampal dendritic structures in adult rats. Methods: The experiments were carried out with male and female wistar rats in our department. The rats were mated and, after birth, the pups were divided into four groups.The first group (control group) pups remained undisturbed with their dam until postweaning day 22. Maternal deprived groups were separated from their dams for 24 hours at postnatal day 4, 9 and 18. The subjects were provided with food and water ad libitum until 3-months-of-age. At the third month, the rats were transcardially perfused, samples were taken from CA1 and CA3 regions of the hippocampus. Tissues were prepared for electron microscopy. Results: When the data were analyzed, there were no differences between male and female rats in both ultrastructure and semiquantitative analysis of axodendritic synapses. The ultrastructure of Group 1 was seen as normal while in the second Group some neurons nuclear envelope made deep invagination into the nucleus. Additionally, axodendritic synapses were found normal. In Group 3, micrographs and axodendritic synapses were showed normal structure. However, in Group 4 in some neurons invaginations were seen similar to Group 2. Axodendritic synapses were found to be normal. Conclusion: These experiments establish that MD in rats produces slight ultrastructural changes and decreases the number of synapses in CA 1 and CA3 subregions of the hippocampus.
\end{abstract}

RÉSUMÉ: Les effets d'une situation anaclitique sur la structure hippocampique chez des rats adultes. Objectifs : Le but de cette étude était d'examiner les effets ultrastructuraux d'une situation anaclitique pendant le développement du système limbo-hypothalamo-hypophyso-surrénalien sur les structures dendritiques de l'hippocampe chez des rats adultes. Méthodes : Les expériences ont été réalisées chez des rats Wistar mâles et femelles dans notre département. Les rats ont été accouplés et les ratons ont été divisés en quatre groupes après la naissance. Les ratons du premier groupe (groupe témoin) sont demeurés auprès de leur mère jusqu'au 22e jour après le sevrage. Les groupes en situation anaclitique ont été séparés de leur mère pendant 24 heures au jour 4,9 et 18 de la période postnatale. Ils avaient accès à la nourriture et à l'eau à volonté jusqu'à l'âge de 3 mois. Au troisième mois, les rats ont été perfusés par voie transcardiale et des échantillons ont été prélevés dans les régions CA1 et CA3 de l'hippocampe. Ces tissus ont été préparés pour étude par microscopie électronique. Résultats : L'analyse des données a montré qu'il n'y avait pas de différence entre les mâles et les femelles quant à l'ultrastructure et à l'analyse semiquantitative des synapses axodendritiques. L'ultrastructure du groupe 1 était normale alors que dans le deuxième groupe, l'enveloppe nucléaire de certains neurones présentait des invaginations profondes dans le noyau. Les synapses axodendritiques étaient normales. Dans le groupe 3, la structure des micrographes et des synapses axodendritiques s'est avérée normale. Cependant dans le groupe 4, des invaginations ont été observées dans certains neurones, comme celles observées dans le groupe 2. Les synapses axodendritiques se sont avérées normales. Conclusion : Ces expériences démontrent qu'une situation anaclitique induit de légers changements ultrastructuraux chez le rat et diminue le nombre de synapses dans les sous-régions CA1 et CA3 de l'hippocampe.

Can. J. Neurol. Sci. 2009; 36: 356-362

Stress is identified as the response to physical or psychological stimulus that disrupts homeostasis. ${ }^{1}$ The stress response includes adaptive physological procedures in mammalians in different situations. Moreover, it can be considered as an alarm system and in mammalians, the stress response is closely linked with the limbic-hypothalamopituitary-adrenal (LHPA) system. ${ }^{1-4}$ Maternal separation (MS) is an important animal model for early life stress in which rat pups are deprived from maternal contact once or repeatedly during the first postnatal weeks and the development of LHPA system is under maternal regulation.5,6 During the so-called stress hyporesponsive period (SHRP) which lasts from approximately postnatal days (PND) 4-14, the dam supresses this system. ${ }^{6}$

\footnotetext{
From the Çukurova University, Faculty of Medicine, Department of Anatomy (PK, MGB, FD), Department of Physiology (EM, EBM), Department of HistologyEmbryology (MK, SP), Adana, Turkey.

Received November 6, 2008. Final Revisions Submitted January 8, 2009. Correspondence to: Pınar Karakaş, Çukurova University, Faculty of Medicine, Department of Anatomy, 01330, Adana, Turkey.
} 
Furthermore, stress-induced increases in adrenal release of glucocorticoids. ${ }^{7}$ Increasing the plasma levels of glucocorticoids in the acute period are life saving but in the following period are harmful and disruptive. ${ }^{8}$ Glucocorticoids affects some brain structures such as the hippocampus disrupt in episodic memory. ${ }^{7}$ The Hippocampus, which belongs to the limbic system, has a high concentration of glucocorticoid receptors..$^{1-4,7-9}$ Besides its function in neuroendocrine regulation, the hippocampus plays an important role in emotional processing, learning and memory. ${ }^{1,10-12}$ Based on these data, some researchers investigated the effects of stress on hippocampal function in laboratory animals and in humans. ${ }^{1,13}$ Moreover, the investigations focussed on neuronal structures like dendritic spines of the hippocampus. Dendritic spines are small protrusions and postsynaptic sites of excitatory input in the mammalian nervous system. ${ }^{14,15}$ It has been suggested that they may play a role in associative memories. ${ }^{16-18}$ Additionally, dendritic spines have been shown to act as biochemical compartments. ${ }^{15,19-22}$ Some ultrastructural analyses of hippocampal neurons have indicated that dendritic spines undergo morphological changes following stress.,23-24

To further understand how the adult brain endures stressful events during early life, the present study examined the ultrastructural effects of maternal separation, during development of the LHPA system, on hippocampal dendritic spines in adult rats.

\section{Materials ANd Methods}

The experiments were carried out with male and female Wistar rats which were obtained from the Experimental Animal Center in Çukurova University in Adana between 2003-2007 in this study. After a habitutation period of one week, four females were mated with one male in transparent polycarbonate boxes (320x460x190 H m/m) containing sawdust bedding in our department's animal laboratory. Pregnant females were transferred separately to clean polycarbonate cages with sawdust. They were checked for litters daily at 09:00h and 17:00h and if litters were found, the day of birth was defined as Day 0 for those litters. From this moment on, the litters were not handled in any way nor were their cages cleaned until the postweaning time (postnatal day 22), to minimize disruption of mother-infant relationships. A total of 24 litters was used in the study. All animals were housed under constant conditions: $12: 12 \mathrm{~h} \mathrm{light} /$ dark cycle (lights on at $07.00 \mathrm{~h}$ ), temperature $\left(23 \pm 2^{\circ} \mathrm{C}\right)$, humidity $(55 \pm 5 \%)$ and entrance was restricted to a limited number of persons. Rat chow and water were provided ad libitum.

All the experimental procedures were carried out in accordance with the experimental protocols approved by the animal care committee of University of Çukurova. All efforts were made to minimize animal suffering during the experiments.

Three experimental groups and one control group were studied. Each group consisted of six pups which were from the same dam of both sexes. Maternal deprived subjects were separated from their mothers for 24 hour at $09.00 \mathrm{~h}$ at the beginning (PND 4), in the middle (PND 9) of the LHPA axis development periods and at PND 18 after LHPA axis. To carry out MS, the dam was removed to another cage while the pups remained in their home cage. The home cage was then transferred to the deprivation room, adjacent to the main colony room and placed on a heating pad at $33^{\circ} \mathrm{C}$. The deprivation room was kept under the same temperature and lighting conditions as mentioned previously. Neither food nor water was available during the deprivation period. After $24 \mathrm{~h}$ the pups were returned to the main room and the mother returned to the home cage. The summary of our groups were as follows:

Group 1(n=6) (the control group)- The pups remained undisturbed with their mother from birth until postweaning day 22 .

Group 2(n=6)- The pups were deprived at PND 4

from their dam for $24 \mathrm{~h}$.

Group 3(n=6)- The pups were deprived at PND 9

from their dam for $24 \mathrm{~h}$.

Group 4(n=6)- The pups were deprived at PND 18

from their dam for $24 \mathrm{~h}$.

In all the deprived and control groups, pups were separated from their mothers and placed in separate cages with four same sex animals per cage at postweaning day 22. From then on, the subjects remained undisturbed with food and water available ad libitum until the age of three months - (young adulthood) - to investigate the ultrastructural effects of early life stress that performed on different development periods of LHPA system on hippocampus.

When the subjects were at young adulthood time, the rats were deeply anesthetized with ksilazin $(10 \mathrm{mg} / \mathrm{kg})$ and ketamin $(80 \mathrm{mg} / \mathrm{kg}$ ) and transcardially perfused with $250 \mathrm{ml} 4 \%$ paraformaldehyde. The brains were waited overnight in the solution. From each brain, the tissue samples were taken from the hippocampal CA1 and CA3 subregions which was $1 \mathrm{~mm}^{3}$ thick. The tissues were immediately placed in $5 \%$ glutaraldehyde buffered at pH 7.4 with Millonig phosphate buffer for four hours. The tissue pieces were subsequently fixed in $1 \%$ osmic acid for two hours. Tissue samples were then dehydrated in graded ethanols, embedded in araldite and processed for electron microscopy using conventional methods.

Spines and axodendritic synapses were analysed by using Zeiss Transmission Electron Microscope EM 900 (OberkochenGermany) at a final magnification of X5000. Only axodendritic synapses from 50 different areas within the $150 \mu \mathrm{m}^{2}$ of the section were randomly selected at a final magnification of X5000

The number of axodendritic synapses were analysed by using SPSS for Windows Version 10.0. For comparison between dependent groups pair t test, for between independent groups one-way ANOVA, for multiple comparisons, Duncan test was applied. From these data, mean and standard deviations were calculated. A level of $\mathrm{p}<0.05$ was considered significant.

\section{RESULTS}

We addressed the ultrastructural effects of early life maternal deprivation on axodendritic synapses of hippocampal CA1 and CA3 subregions in the adulthood time. When we analyzed our data according to gender, we found no differences in male and female rats so we did not divide into sexes for analysis. As shown in the Table, semiquantitative analysis of axodendritic synapses revealed that maternal deprivation reduced the number of synapses ( $p<0,05$, one-way ANOVA, Tukey post hoc test) in $\mathrm{CA} 1$ and CA3 subregions in groups which were separated on 


\begin{tabular}{|c|c|c|c|}
\hline Group & $\begin{array}{c}\text { CA1 region } \\
\text { (mean } \pm \text { standard deviation) }\end{array}$ & $\begin{array}{c}\text { CA3 region } \\
\text { (mean } \pm \text { standard deviation) }\end{array}$ & $\begin{array}{l}P \text { value }{ }^{* *} \\
\text { (pair } t \text { test) }\end{array}$ \\
\hline Group 1 & $38,3 \pm 1,9$ & $38,1 \pm 1,7$ & 0,4 \\
\hline Group 2 & $35,7 \pm 2,2^{* * *}$ & $34,6 \pm 2,7^{* * *}$ & 0,000 \\
\hline Group 3 & $33,1 \pm 2,1^{*}$ & $31,9 \pm 2,6^{*}$ & 0,000 \\
\hline Group 4 & $38,7 \pm 2,2$ & $38,3 \pm 2,1$ & 0,02 \\
\hline $\begin{array}{c}\text { P value } \\
\text { (ANOVA) }\end{array}$ & 0,000 & 0,000 & \\
\hline
\end{tabular}

*** $\mathrm{p}<0,001$ Between Group 1 and Group 2 (Duncan test); ${ }^{*} \mathrm{p}<0,001$ Between Group 1 and Group 3 (Duncan test); **Between CA1 and CA3 in groups (pair t test)

PND 4 (Group 2) and PND 9 (Group 3) compared to the number of non-separated control group's (Group 1) synapses. Additionally, the number of synapses in CA3 subregion were significantly lower than CA1 area in Group 2 and 3 ( $\mathrm{p}=0.000$, $\mathrm{p}=0.000$ respectively). However, in Group 4 (separated PND 18), the number of axodendritic synapses were similar to the control's in both areas ( $\mathrm{p}=0.02, \mathrm{p}=0.4$ respectively). Figure 1 showed the cumulation of axodendritic synapses in CA1 and CA3 regions according to the groups.

\section{Electron Microscopic Findings}

Group 1. The nerve cells, the glial cells and nerve fibres exhibited normal ultrastructure. Additionally, dendritic spines and axodendritic synapses were also seen normal (Figure 2).

Group 2. Although most of the nerve cell showed normal ultrastructure, in some neurons the nuclear envelope made deep invaginations into the nucleus. Moreover, some empty vacuoles were found between axon and myelin sheath in some myelinated nerve fibres. In cytoplasm, the organelles exhibited normal structure like first group. The ultrastructure of the capillary wall determined normal. Axodendritic synapses were also seen normal (Figure 3). Furthermore, some of the dendrites revealed degenerative changes, with membranous whorl like structures (Figure 4).

Group 3. The nerve cells and myelinated nerve fibres exhibited normal structure. The glial cells also showed normal ultrastructure. In axodendritic synapses, synaptic vesicles and a few organells were seen. Myelinated nerve fibres exhibited normal structure. Dendritic spines were seen in several shapes according to the slice level (Figures 5 and 6).

Group 4. The nerve cell revealed normal structure with nucleus and cytoplasmic organelles. However, in some nerve

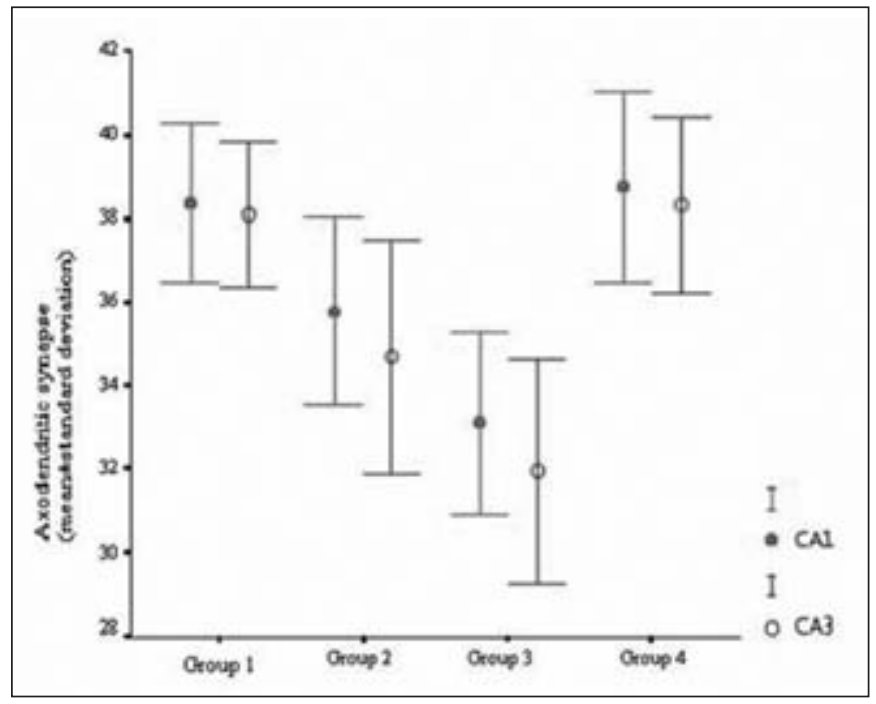

Figure 1: The cumulation of axodendritic synapses in CAI and CA3 regions according to the groups.

cells, the nuclear envelope of nucleus made some deep invaginations into the nucleus as seen in Group 2 (Figure 7). Although most of the dendrites exhibited normal structure, some showed membranous whorl like structures. Furthermore, some of the nerve cells disclosed flamentous structures in the nucleus. Axodendritic synapses, glial cells and capillaries showed normal ultrastructure (Figure 8). 


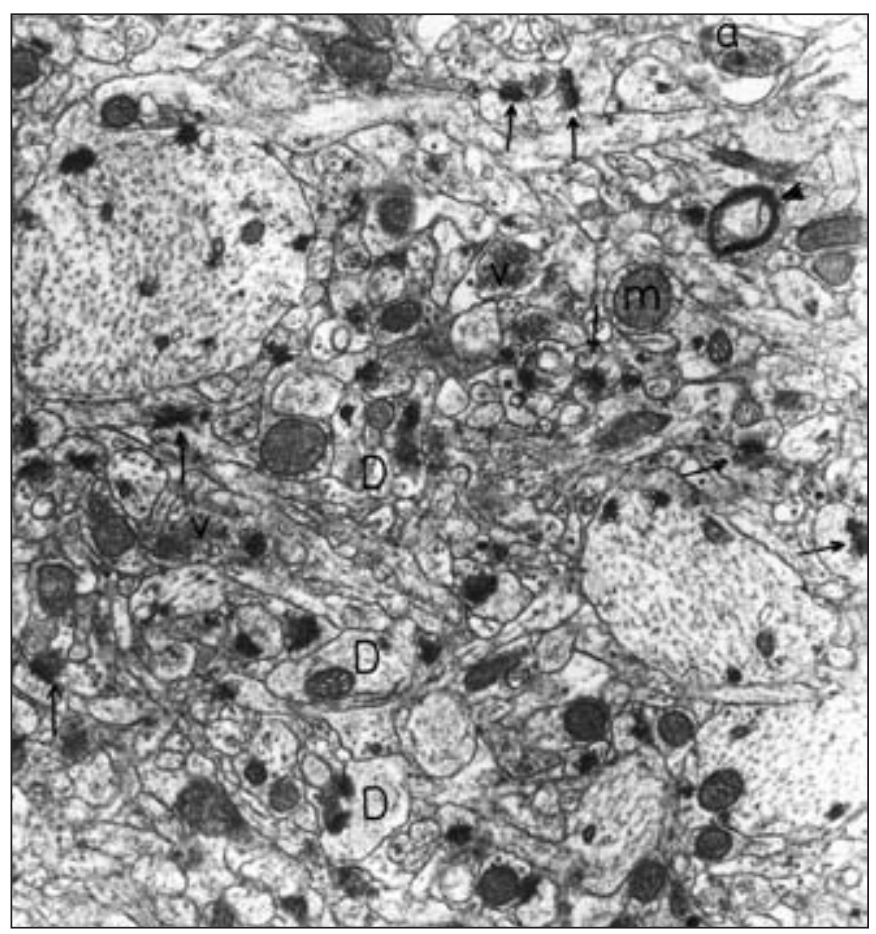

Figure 2: Group 1. CA1 region. The nerve cells exhibits normal structure. In dendrites $(D)$, mitochondria $(m)$ are seen. Synaptic vesicles (v) are found in presynaptic region of axons (a). Axodendritic synapses (arrows) are seen. Myelinated nerve fibers (arrow heads) (original magnification X 20,000).

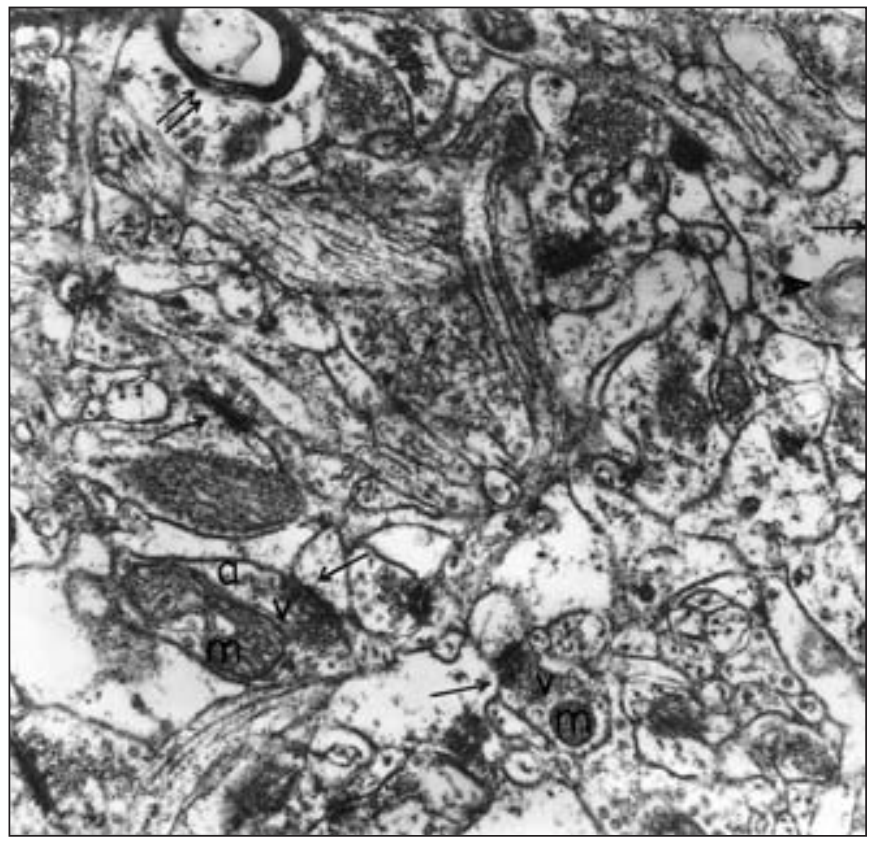

Figure 4: Group 2. CA1 region. In some dendrites, membranous whorl like structure are found (arrow head). Axodendritic synapses (arrows), synaptic vesicles $(v)$, mitochondria $(m)$, myelinated nerve fibers (double arrow) (original magnification $X$ 40,000).

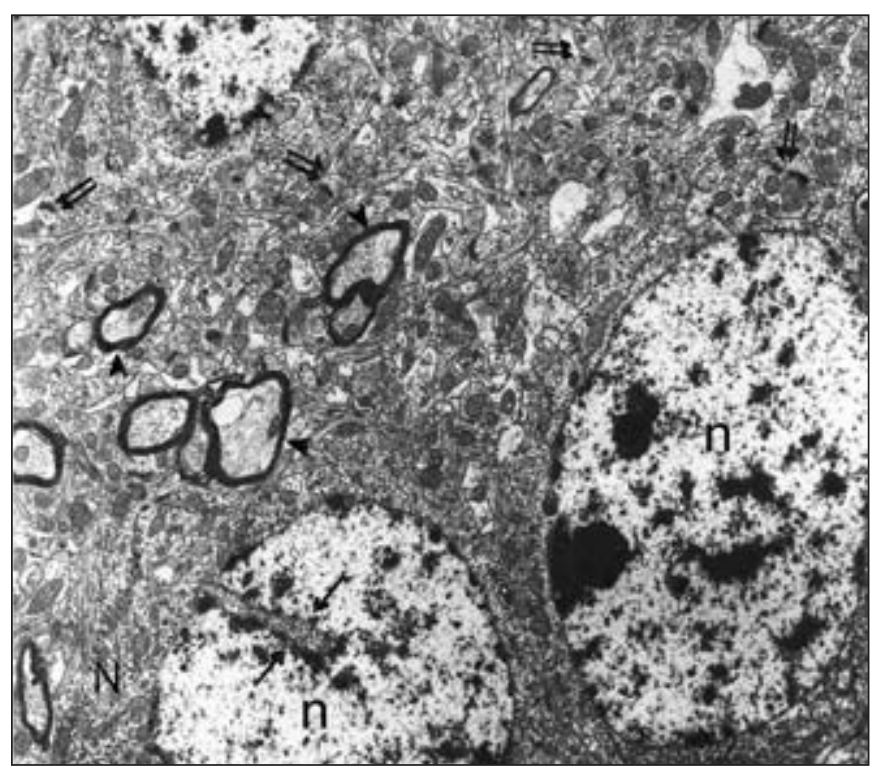

Figure 3: Group 2. CA1 region. Neurons $(N)$ show normal structure. In some neurons, nuclear envelope made deep invaginations (arrows) into the nucleus (n). Axodendritic synapses (double arrows) are seen normal. Myelinated nerve fibers (arrow heads) (original magnification $X$ 10,100).

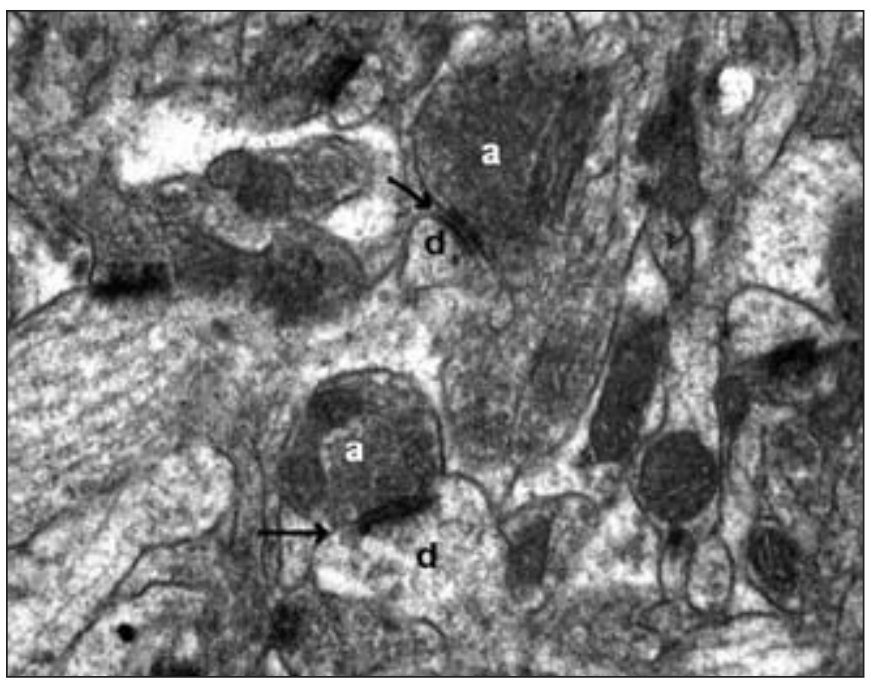

Figure 5: Group 3. CA3 region. Axodendritic synapses (arrows) are seen in normal structure. Axon (a), dendrite (d) (original magnification $X$ $25,000)$.

\section{Discussion}

The results of these experiments indicate that early maternal deprivation in different development periods of the LHPA axis results in some morphological changes in learning and memory sites of the hippocampus in adult rats. Thus, our semiquantitative study also revealed that early postnatal stressful emotional experience alters the synaptic development in the subregions of CA1 and CA3 of hippocampus. 


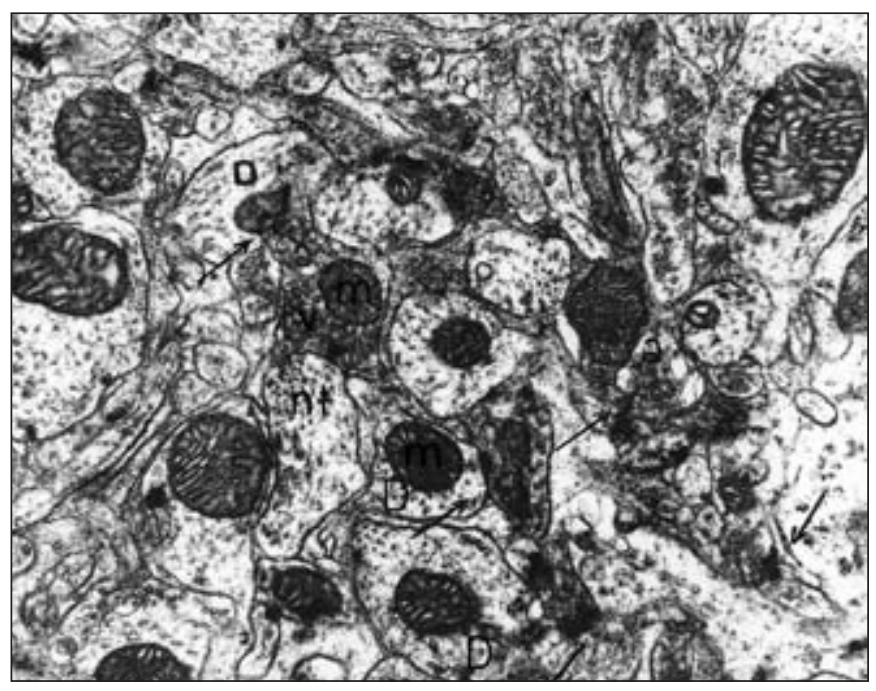

Figure 6: Group 3. CA3 region. In axodendritic synapses (arrows), synaptic vesicles $(v)$ and mitochondria $(m)$ are seen. Axon $(a)$, dendrite (D), neurotubule (nt) (original magnification X 32,000).

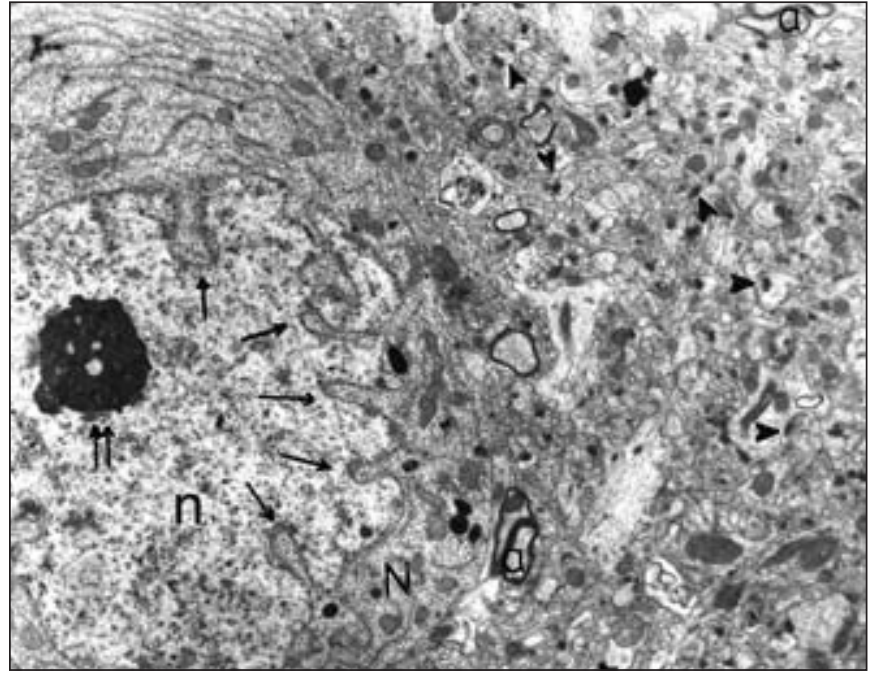

Figure 7: Group 4. CA1 region. In some of the nerve cells $(N)$, the nuclear envelope of nucleus makes deep invaginations (arrows) into the nucleus (n). There is a flamentous structure (*) near the nuclear envelope. Nucleolus (double arrows), myelinated nerve fiber $(a)$, axodendritic synapses (arrow heads) (original magnification X 8,100).

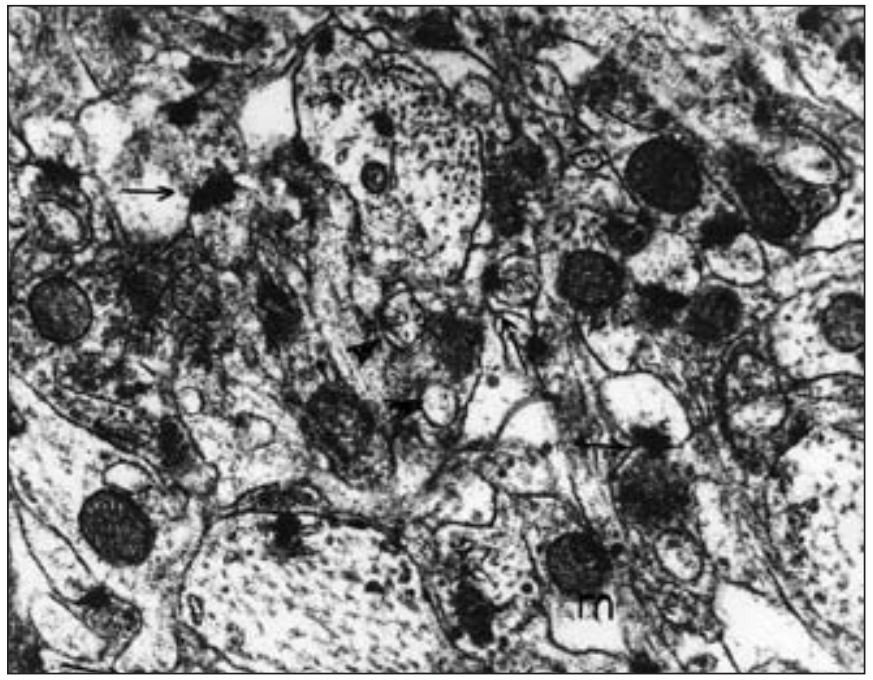

Figure 8: Group 4. CA3 region. Axodendritic synapses (arrows) are seen normal. In some axons (arrow head), mitochondria $(m)$ have slight structural changes (original magnification X 32,000).

study, we chose the first model which the pup is deprived from all familiar surroundings and placed in a separate environment.

Moreover, in planning the duration of maternal deprivation, this manipulation involves removal of the pup from dam for time periods of at least one hour or the other form constitutes for a single period of 24 hour on one specific postnatal day between birth and weaning. ${ }^{5}$ The effects of single period of MD were dependent on the age of the pup at the time of deprivation. PND 4-14 are characterized by low basal LHPA activity, this age has been considered as SHRP of rat development and is characterized by an adrenal insensitivity to stimulation with ACTH, minimal corticosterone elevations in response to most stressors. ${ }^{5,6,25,30-35}$ Major advantage to perform single MD paradigm for this study, is it provides to investigate the specificity of the manipulation in development periods of pup. Furthermore, the rat was determined to be a useful experimental model for early developmental events and the ontogeny of rats is rapid, well known. Additionally, in general many aspects of neuronal and physiological development in rats are predictive for humans ${ }^{36}$ According to this data, we preferred rats for this experimental study. 
The hippocampus is the central component of limbic circuitry and shows morphological and functional vulnerability to some neuroendocrinological changes such as ischemia, head trauma, hypoglycemia and aging. ${ }^{37,38}$ Thus, the human hippocampus undergoes atrophy after traumatic stress, depression and Cushing's syndrome. ${ }^{13}$ After discovery of glucocorticoid receptors in this area, studies which investigated the effects of stress, were increased on hippocampus. ${ }^{1,9}$ However, it was observed that in rats after 21 days of daily stress, hippocampal CA3 pyramidal neurons had a decrease in apical dendritic branching and dendritic length. 1,4,13,39 Therefore, the decision to examine the hippocampus in the current paper was based upon the data that early stress alters the morphology of this area in the mature brain..$^{3,23,26,32,39-42}$ In the hippocampus, most excitatory synapses are located on dendritic spines which were first described by Ramon y Cajal in 1891. ${ }^{17-19,43,44}$ It was emphasized that spines are stable storages of long term memory. Moreover, there are also data that learning alters the spine density in the hippocampus. ${ }^{16,17}$

In our experimental paradigm, when we analyzed the ultrastructure of the hippocampal CA1, CA3 regions of Group 2 which was separated from dam at the beginning of the SHRP (PND 4), it was observed that in some neurons, the nuclear envelope made deep invaginations into the nucleus, empty vacuoles between axon and myelin sheath and membranous whorl like structures were seen. However, axodendritic synapses were seen normal. Due to semiquantitative analysis, the number of axodendritic synapses was found as $35.7 \pm 2.2$ in CA1 region and 34.6 \pm 2.7 in CA3 region. All these data are in contrast to the control group's ultrastructure and number of synapses: lower in Group 2. The ultrastructural appearance and decreased number of synapses are similar to previous reportswhich also indicated that early stress caused morphological and functional changes ${ }^{3,13,39}$

As discussed recently, MD pups had some neuroendocrinological and behavioural effects. Since some of these deficits are similar to abnormality observed in schizophrenic patients, MD has been proposed as an interesting model for this disorder. ${ }^{5,30}$ Thus, Ellenbroek et $\mathrm{al}^{45}$ have shown that a single 24 hour period of MD at typically PND 9 increases apomorphine susceptibility and decreases prepulse inhibition in rats, also seen in schizophrenic patients. Additionally, it was estimated that beginning at PND 8, MD alters the LHPA axis so the pup is responsive to mild stress. ${ }^{46}$ In our Group 3 (deprived at the midterm of SHRP- PND 9), although in micrographs it was observed that the nerve cells, glial cells, myelinated nerve fibres were in normal structure, the number of synapses were significantly lower than the controls $(33.1 \pm 2.1,31.9 \pm 2.6$ in CA1 and CA3 regions respectively). This is in concordance with data that early stress alters the production of synapses in hippocampus. ${ }^{34}$

The last group deprived after SHRP on PND 18, deep nuclear envelope invaginations and membranous whorl like structures were found in some neurons similar with the second group. Some flamentous structures were also seen in the nerve cell nucleus in this group. Furthermore, axodendritic synapses were found normal. In semiquantitative estimation, number of synapses were found as controls' values $(38.7 \pm 2.2$ in CA1 and $38.3 \pm 2.1$ in CA3). It was interesting that there were some effects on ultrastructure due to MD but not on synapses. It was reported that MD at PND 18-20 days results in profound changes of the LHPA system. ${ }^{6}$ Even though the post SHRP deprived pup shows a normal corticosterone response to mild stressors, 24h of MD enhances this response and pups at this age are in a transitional process. We think that also after SHRP pups are still dependent on the dam for the regulation of the LHPA system.

Here, we report our findings on the effects of MD conducted during beginning, midterm and post LHPA system development, on hippocampal ultrastructure and synapses in adult rats. Overall, the results show that, depending on the age of rat, MD led to different long-term effects on morphology and synapses. We observed a stress-induced decreasing number of synapses and ultrastructural changes seen in hippocampal subregions CA1, CA3 in rats in Group 2 and 3 as compared with control group. Although some electron microscopic changes were found in Group 4, the number of synapses were similar to controls. This finding may be due to the fact that the LHPA system still needs the dam's presence for normal development and disruption of dam-pup interaction alters this system at every level. Moreover, after SHRP, maternal contact remains essential for rat development.

In conclusion, the present experiments establish that MD, an important stress factor in rats, produces ultrastructural changes and decreases the number of synapses in CA1 and CA3 subregions of the hippocampus.

\section{REFERENCES}

1. Fuchs E, Flügge G, Ohl F, Lucassen P, Vollmann-Honsdorf GK, Michaelis T. Psychosocial stress, glucocorticoids, and structural alterations in the tree shrew hippocampus. Physiol Behav. 2001; 73:285-91.

2. Magarinos AM, McEwen BS. Stress-induced atrophy of apical dendrites of hippocampal CA3c neurons: comparison of stressors. J Neurosci. 1995; 69:83-8

3. Fuchs E, Uno H, Flügge G. Chronic psychosocial stress induces morphological alterations in hippocampal pyramidal neurons of the tree shrew. Brain Res. 1995; 673:75-82.

4. Lopez JF, Akil H, Watson SJ. Role of biological and psychological factors in early development and their impact on adult life. Biol Psychiatry. 1999; 46:1461-71.

5. Lehmann J, Pryce CR, Bettschen D, Feldon J. The maternal separation paradigm and adult emotionality and cognition in male and female wistar rats. Pharmacol Biochem Behav. 1999; 64:705-15.

6. Schmidt M, Okimoto DK, Dent W, Gordon MK, Levine S. Maternal regulation of the hypothalamic-pituitary-adrenal axis in the 20day-old rat: consequences of laboratory weaning. J Neuroendocrinol. 2002; 14:450-7.

7. Francis DD, Meaney MJ. Maternal care and the development of stress responses. Curr Opin Neurobiol. 1999; 9:128-34.

8. Ganong WF. Adrenal medulla and adrenal cortex. In: Review of medical physiology. 18th ed. Appleton and Lange; p. 347.

9. Lambert KG, Buckelew SK, Staffiso-Sandoz G, Gaffga S, Carpenter W, Fisher J, et al. Activity-stress induces atrophy of apical dendrites of hippocampal pyramidal neurons in male rats. Physiol Behav. 1998; 65:43-9.

10. Wallenstein GV, Eichenbaum H, Hassehno ME. The hippocampus as an associator of discontiguous events. Trends Neurosci. 1998; $21: 317-23$

11. Moser MB, Trommald M, Andersen P. An increase in dendritic spine density on hippocampal CA1 pyramidal cells following spatial learning in adult rats suggests the formation of new synapses. Proc Natl Acad Sci. 1994; 91:12673-5.

12. Magarinos AM, McEwen BS, Flügge G, Fuchs E. Chronic psychosocial stress causes apical dendritic atrophy of hippocampal CA3 pyramidal neurons in subordinate tree shrews. J Neurosci. 1996; 16:3534-40. 
13. Magarinos AM, Verdugo JMG, McEwen BS. Chronic stress alters synaptic terminal structure in hippocampus. Proc Natl Acad Sci. 1997; 94:14002-8.

14. Zito K, Murthy VN. Dendritic spines. Curr Biol. 2002; 12:R5.

15. Dunaevsky A, Tashiro A, Majewska A, Mason C, Yuste R. Developmental regulation of spine motility in the mammalian central nervous system. Proc Natl Acad Sci. 1999; 96:13438-43.

16. Segal M. Rapid plasticity of dendritic spine: hints to possible functions. Prog Neurobiol. 2001; 63:61-70.

17. Shors TJ, Chua C, Falduto J. Sex differences and opposite effects of stress on dendritic spine density in the male versus female hippocampus. J Neurosci. 2001; 21:6292-7.

18. Harris KM. Calcium from internal stores modifies dendritic spine shape. Proc Natl Acad Sci. 1999; 96:12213-15.

19. Reid C. The role of dendritic spines: comparing the complex with the simple. Eur J Pharmacol. 2002; 447:173-6.

20. Spacek J, Harris KM. Three-dimensional organization of cell adhesion junctions at synapses and dendritic spines in area CA1 of the rat hippocampus. J Comp Neurol. 1998; 393:58-68.

21. Boyer C, Schikorski T, Stevens CF. Comparison of hippocampal dendritic spines in culture and in brain. J Neurosci. 1998; 18: 5294-300.

22. Segal M. Dendritic spines for neuroprotection: a hypothesis. Trends Neurosci. 1995; 18:468-71.

23. Galea LAM, McEwen BS, Tanapat P, Deak T, Spencer RL, Dhabhar FS. Sex differences in dendritic atrophy of CA3 pyramidal neurons in response to chronic restraint stress. J Neurosci. 1997; 81:689-97.

24. Papa M, Segal M. Morphological plasticity in dendritic spines of cultured hippocampal neurons. J Neurosci. 1996; 71:1005-11.

25. Suchecki D, Nelson DY, Van Oers H, Levine S. Activation and inhibition of the hypothalamic-pituitary-adrenal axis of the neonatal rat: effects of maternal deprivation. Psychoneuroendocrinol. 1995; 20:169-82.

26. Roceri M, Cirulli F, Pessina C, Peretto P, Racagni G, Riva MA. Postnatal repeated maternal deprivation produces age-dependent changes of brain-derived neurotrophic factor expression in selected rat brain regions. Biol Psychiatry. 2004; 55:708-14.

27. Workel JO, Oitzl MS, Ledeboer A, de Kloet ER. The Brown Norway rat displays enhanced stress-induced ACTH reactivity at day 18 after 24-h maternal deprivation at day 3. Brain Res Dev Brain Res. 1997; 103:199-203.

28. Greisen MH, Altar CA, Bolwig TG, Whitehead R, Wörtwein G. Increased adult hippocampal brain-derived neurotrophic factor and normal levels of neurogenesis in maternal separation rat. J Neurosci Res. 2005; 79:772-8.

29. Levine S. Influence of psychological variables on the activity of the hypothalamic-pituitary-adrenal axis. Eur J Pharmacol. 2000; 405:149-60.

30. Ellenbroek BA, Cools AR. Early maternal deprivation and prepulse inhibition. The role of the postdeprivation environment. Pharmacol Biochem Behav. 2002; 73:177-84.

31. Levine S. Primary social relationships influence the development of the hypothalamic-pituitary-adrenal axis in the rat. Physiol Behav. $2001 ; 73: 255-60$.
32. Gould E, Tanapat P. Stress and hippocampal neurogenesis. Biol Psychiatry. 1999; 46:1472-9.

33. Oitzl MS, Workel JO, Fluttert M, Frösch F, de Kloet ER. Maternal deprivation affects behaviour from youth to senescence: amplification of individual differences in spatial learning and memory in senescent Brown Norway rats. Eur J Neurosci. 2000; 12:3771-80.

34. Schmidt M, Enthoven L, van der Mark M, Levine S, de Kloet ER, Oitzl MS. The postnatal development of the hypothalamicpituitary-adrenal axis in the mouse. Int J Devl Neurosci. 2003; 21:125-32.

35. Schmidt M, Enthoven L, van Woezik JHG, Levine S, de Kloet ER, Oitzl MS. The dynamics of the hypothalamic-pituitary-adrenal axis during maternal deprivation. J Neuroendocrinol. 2004; 16 : 52-7.

36. Kuhn CM, Schanberg SM. Responses to maternal separation: mechanisms and mediators. Int J Devl Neurosci. 1998; 16: 261-70.

37. Magarinos AM, McEwen BS. Stress-induced atrophy of apical dendrites of hippocampal CA3c neurons: involvement of glucocorticoid secretion and excitatory aminoacid receptors. J Neurosci. 1995; 69:89-98.

38. McEwen BS. Effects of adverse experiences for brain structure and function. Biol Psychiatry. 2000; 48:721-31.

39. Andersen SL, Teicher MH. Delayed effects of early stress on hippocampal development. Neuropsychopharmacol. 2004; 29: 1988-93.

40. Poeggel G, Helmeke C, Abraham A, Schwabe T, Friedrich P, Braun $\mathrm{K}$. Juvenile emotional experience alters synaptic composition in the rodent cortex, hippocampus, and lateral amygdala. Proc Natl Acad Sci. 2003; 100:16137-42.

41. Lehmann J, Russig H, Feldom J, Pryce CR. Effect of a single maternal separation at different pup ages on the corticosterone stress response in adult and aged rats. Pharmacol Biochem Behav. 2002; 73:141-5.

42. Brunson KL, Eghbal-Ahmadi M, Bender R, Chen Y, Baram TZ. Long-term, progressive hippocampal cell loss and dysfunction induced by early-life administration of corticotropin-releasing hormone reproduce the effects of early-life stress. Proc Natl Acad Sci. 2001; 98:8856-61.

43. Trommald M, Hulleberg G. Dimensions and density of dendritic spines from rat dentate granule cells based on reconstructions from serial electron micrographs. J Comp Neurol. 1997; 377: $15-28$.

44. Fiala JC, Feinberg M, Popov V, Harris KM. Synaptogenesis via dendritic filopodia in developing hippocampal area CA1. J Neurosci. 1998; 18:8900-11.

45. Ellenbroek BA, Cools AR. The long-term effects of maternal deprivation depend on the genetic background. Neuropsychopharmacol. 2000; 23:99-106.

46. Van Oers HJJ, de Kloet ER, Levine S. Early vs. late maternal deprivation differentially alters the endocrine and hypothalamic responses to stress. Dev Brain Res. 1998; 111:245-52. 